\begin{tabular}{c} 
Volume and Issues Obtainable at Center for Sustainability Research and Consultancy \\
Journal of Business and Social Review in Emerging Economies \\
ISSN: 2519-089X (E): 2519-0326 \\
Volume 6: No. 1, March 2020 \\
CSRᄃ \\
Journal homepage: www.publishing.globalcsrc.org/jbsee \\
\hline
\end{tabular}

\title{
Socio-economic and Socio-demographic Determinants of Women Empowerment: Empirical Evidence from the Districts of Ghizer and Gilgit, Northern Pakistan
}

\author{
${ }^{1}$ Saranjam Baig, ${ }^{2}$ Salma Nusrat, ${ }^{3}$ Salma Bano \\ ${ }^{1}$ Visiting Assistant Professor, Sultan Qaboos University, Muscat Oman /Assistant Professor/Director \\ Centre for Research on China-Pakistan Economic Corridor \\ Karakoram International University Gilgit, Pakistan: saranjam.baig@alumni.cgu.edu \\ ${ }^{2}$ Research Associate, Centre for Research on China-Pakistan Economic Corridor (CPEC) Karakoram \\ International University Gilgit, Pakistan \\ ${ }^{3}$ Assistant Professor, School of Arts, Architecture, and Design, National University of Science and \\ Technology (NUST) Islamabad, Pakistan
}

\begin{tabular}{l} 
ARTICLE DETAILS \\
\hline History \\
Revised format: February 2020 \\
Available Online: March 2020
\end{tabular}

\section{Keywords}

GDP Women Empowerment, Women Decision making, Women Participation

\section{JEL Classification:}

A14, Z1, Z13, J1

\section{ABSTRACT}

Women empowerment has remained the most deliberate subject and many social scientists have explored this subject in their respective fields. Women empowerment has assorted dimensions, however this study focuses only on two dimensions' women decision making and women participation. Primarily, this study constructs two indices of women empowerment which are women decision making index and women participation index based on different components computed using principal component analysis. This research uses primary data, where the data is collected from households of the respective regions using two-stage cluster sampling technique. Secondly, this paper scrutinizes the socio-demographic and economic causes of women empowerment in Gilgit and Ghizer districts of Gilgit-Baltistan using structural equation model. The scores of women empowerment indexes indicate that in terms of decision making, women of Ghizer district are more empowered as compared to Gilgit district whereas in terms of women participation women of Gilgit are more empowered. Amongst the socioeconomic and demographic variables, education level shows significant and positive association with both indexes of empowerment. Correspondingly, standard of living of the household demonstrates a significant relationship with women decision making showing that the better the standard of living the more empowered will be the women.

(C) 2020 The authors, under a Creative Commons Attribution-

\section{OPEN ACCESS}

NonCommercial 4.0

Corresponding author's email address: saranjam.baig@ alumni.cgu.edu

Recommended citation: Baig, S., Nusrat, S. \& Bano, S., (2020). Socio-economic and Sociodemographic Determinants of Women Empowerment: Empirical Evidence from the Districts of Ghizer and Gilgit, Northern Pakistan. Journal of Business and Social Review in Emerging Economies, 6(1), 8198

DOI: $10.26710 /$ jbsee.v6i1.1031 


\section{Introduction}

History discloses that women have always been deprived and have suffered a lot on the basis of race, culture, region and have been prone to abuse, harassment, rape, poverty, malnutrition and other ill social \& economic problems in societies (Mandal, 2013). Women empowerment and gender equality are the most calculated subject matters and lately these subjects have grabbed the attention of authors from different fields of social sciences. Women's empowerment is well-thought-out to be a common remedy to enhance gender equality and well-being of nations (Blumberg, 2005). By gaining more economic power, women gains say in household decision making and can spend money disproportionately on anything they want like health, nutrition and education.

As stated earlier empowering women has always been a major goal of nations worldwide and it is of prodigious significance particularly in developing countries resembling Pakistan where majority of the mass is beneath the poverty line (Khan and Ali, 2016). Men and women both are imperative parts of any culture nonetheless in male dominated societies, female population is the underprivileged and demoted group of society (Rasul, 2014). According to Day-Hookoomsing (2002) inclusive development is not likely when it lacks the dynamic involvement of women. Henceforth, women's empowerment is not only the widespread discussion of the government, development agencies and non-governmental organizations (NGOs) relatively, it is an approach to bring happiness in whole families, communities and nations. According to United Nations, 2018 SDGs one major component of growth and communal development of country was women empowerment. Gender parity and empowerment of females has remained one major goal of Sustainable Development Goals.

Many government and non-government organizations are working to empower women in countries where women are underprivileged of their basic rights in urban as well as rural regions of Pakistan. According to UNFPA Pakistan, each woman has the right to exercise her reproductive rights and to be secure from cruelty and distressing practices in both the development and humanitarian situations. As reported by an organization United Nations Women 1 only by safeguarding the rights of women and girls across all the others goals of SDGs will we get to justice and inclusion, economies that work for all, and sustaining our shared environment now and for future generations. Pakistan's 2025 vision is to focus on five modules2 of women empowerment into its objectives, containing actions that encourage women's self-worth, right to regulate their choices, access to opportunities and resources, right and power to control their lives inside and outside home and capability to effect social change. But, these still stay outside of the grip of women in Pakistan.

Talking about the stance of Pakistan worldwide in the Global Gender Gap Index, according to GGI 2017 report, Pakistan was ranked the second worst country. The major components used to estimate Gender Gap Index are economic participation and opportunity, educational attainment, health \& survival and political empowerment. Pakistan remains the region's lowest-ranked country and second-to-last ranked overall. This means that Pakistan needs to work even harder to empower women and girls by sending them to schools for higher education, giving them better health facilities, allowing them to participate in labor force and giving them decision making power.

As discussed earlier women are very important fragment of the communal structure in every country, nevertheless despite this fact, they habitually face a lot of problems in their way to attain their basic rights whether at home, in society or at work place. With reference to census 2017, the total population of Pakistan is 207.77 million out of which, 101.323 million are females. This means approximately half the people in Pakistan are women. Out of 101.32 million females, 64.89 million live in the rural areas of Pakistan and rest 36.43 billion are living in the urban regions. The statistics clearly prevails that more than

1 http://www.unwomen.org/en

2 https://pakistan.unfpa.org/en/topics/womens-empowerment 3 http://www.finance.gov.pk/survey/chapters_18/12-Population.pdf 
half of the female population are residents of the rural regions. Hence, focusing on the empowerment of rural women can bring positive contributions. If these women are brought into the work force, development in Pakistan will increase manifold. Women in the rural areas of Pakistan are deprived of their basic rights and less of the women are even aware of their rights or are less empowered. Knowing the importance of women empowerment this study aims to analyse the stance of women in the northern regions of Pakistan particularly two districts Gilgit and Ghizer using different indices of women empowerment. Furthermore, the socio-economic and socio-demographic determinants of women empowerment are examined. So, this study hypothesizes that socio-economic and demographic variables do effect women empowerment. The below sections include literature review, research methodology, results \& discussions and conclusion.

\section{Literature Review}

Women empowerment has remained a topic of concern for many researchers and a lot of research has been conducted on this topic since a long while. Some of the relevant studies are jotted down in the below section. A study by Kabeer (2003) defines women's empowerment as a progression of providing capability to the abandoned women to change the forthcoming plan in their lives. This capability confirms access to communal and physical resources and to organizations where decision-making is handled. Moreover, the author explains IFAD (1999) discussion on the four processes leading to women's empowerment: changes in women's movability and socialization, changes in women's labour patterns, changes in women's access to and control over resources; and changes in women's control over decisionmaking.

Women's economic empowerment is considered a right of women and an essential component for maintainable development and pro-poor growth. High female earnings result in larger investment in children's education (OECD,2012). According to Mehra (1997) women all over the world take part in the production sector to earn income and ratio of their participation is low as compared to men. Although many Non-Government organizations(NGOs) have worked on women empowerment however the gender gap remains. Addressing the basic human needs and focusing on the participatory approaches for women empowerment is the key for economic development. The author has discussed four dimensions for wellbeing of women which are life expectancy, girls' enrolment in primary school, total fertility rate and access to contraception. The results show that interferences that augments women's choice by increasing their excess to employment enhances women's capability to make choices. Moreover, it is claimed that investment in women's education and health influences birth rates and can enhance the well-being of their children. Very tiny is being capitalized in women' s productive lives, where the prospects lie for reducing poverty and improving women's lives. In the rural areas of developing countries, the number of women in poverty is quite high and in increasing trend. Investment in women's lives is important as their earning goes directly towards nutrition and education of children.

According to Floro, Tornquist and Tas, (2009) economic crisis is said to affect women's empowerment in developing countries in short and long run. Economic crisis leads to job loss, decrease in earnings among self-employed women, increase in amount of unpaid work, increase in girl's dropout rate from school and lead to increase in level of violence against women and limited access to health and other support services. Furthermore, they argued that although economic crisis has negative impact of women empowerment, but it can be used as an opportunity to alter supremacy structures, make economic and social strategies more gender aware. Such situations provide opportunity for organizations to identify and respond to women empowerment needs.

A study by khan and Ali, (2016) investigated the socio-empowerment of women in Gilgit-Baltistan with special focus on the role of Local Supportive organizations in the region. They argued that females' right to use the financial resources increase the family's income and affects women empowerment positively. When women are financially independent they became capable of decision making at household level regarding their child's education, marriage and political freedom. Murtaza (2012) conducted a similar study in Gilgit and argued that higher education boosts women's knowledge and helps women play an 
active role in the whole society. And it also helps women in building their self-confidence, lack of education snatches their independence and they rely on their husbands.

Empowered women are considered to plays a vital role in family's budget making process and for human development it is really to empower women (Niaz, Ali and Rukhsana, 2010). Moreover, educated families are assumed to be more encouraging for empowering women to get employed and to take part in decision making process at household level. Furthermore, education and empowerment are found to be positively associated with each other, educated women are mentally progressive and can tackle family issues easily as compared to other women.

Likewise, education is considered to be one significant determinant of women empowerment. Based on the evidence from Southern Punjab Haq, Jali and Islam, (2017) stated that education must be taken on the priority as for women empowerment one major component is education. Their study inspected the association among education and women empowerment using primary data and also revealed that family structure is another major deriving component of women's participation in decision making.

A study by Sultana, (2011) argued that men in rural societies of Bangladesh have greater power in family's decision-making while women are living a suppressed life. A multiple linear regression was employed to find the causes of women's decision-making and women self-sufficiency, the results showed that educational level, income, employment and gender-based responsiveness are significant determinants of women's decision making in household and for a prosperous family husband and wife's cooperation and involvement in household decision making is mandatory.

According to some studies like Parveen and Leonhäuser (2005) have characterized causes of women's empowerment as individual, household, and sociocultural. To the extent that individual-level determinants are concerned, many researchers have determined that sequential age is a noteworthy and positive factor of women's empowerment (e.g., Khan \& Awan, 2011; Nayak \& Mahanta, 2009; Parveen \& Leonhäuser, 2005; Rahman, Karmaker, \& Mia, 2009; Tareque, Haque, Mostofa, \& Islam, 2007; Wiklander, 2010).

Similarly, khan et.al., (2010) explored the determining factors of women empowerment for Rawalpindi Pakistan grounded on 300 sample for women between 15 to 49 age group. Education level, political participation and working for salaried job of women were found to be vital contributing factors of women empowerment.

Moreover, socio-economic causes of women empowerment were explored for Cholistan Desert, Pakistan by Soharwardi, Khan and Khalid, (2014) using factor analysis and principal component analysis to confirm validity and reliability of scales. A stepwise linear regression model is used to examine the determinants of women empowerment and found positive and important relationship of women empowerment with job type of wife, education level of husband and resources possessed by wife. Women empowerment and economic development are interconnected that is women empowerment alters decision making which is said to directly affect economic development whereas economic development is not the only determinant of women empowerment. Furthermore, women empowerment is found to contribute towards welfare of children in terms of nutrition and health and the study further argued that absence of government's determination and absence of elementary structure required to handle the problem have led path to resolve the glitches linked to women empowerment.

Islamic states are considered to have less women empowerment whereas, Chaudhry, Nosheen and Lodhi (2012) argued that the statement of less empowerment in Islamic countries is a delusion and the authors tried to eliminate this misconception through analysing a district of southern Punjab as it is considered one of the backward regions of Pakistan. Islamic notion of women empowerment is determined through some socio-economic and other social factors. The results show that women's years of schooling, 
employment status and women's education index of household tends to have positively substantial influence on women's empowerment whereas fear from husband/father is found to have negative association with women empowerment. Women empowerment is one of the historic concerns of modern development and according the authors the lone method to empower women and to give them their status implementation of Islamic laws in a country like Pakistan is mandatory.

Additionally, investment in women's education is considered to bring knowledge about their rights, obligation and freedom (Shoaib, Saeed \& Cheema, 2012). This study measured women empowerment based on choice and freedom given to women at household level in spending money, freedom to vote, freedom to go out and purchasing of good and services. Education level and women's empowerment are found to have positive association at household level. As education is an entry level to opportunities and at the same time can have spreading effect within the family as well as across the generation.

Another study by Noureen (2015) explored the effect of higher education on the lives of women and education is the only mean to empower women in a patriarchal society like Pakistan. The author further elaborated that sometimes girls don't get the chance to complete their education either due to early marriages or due to poverty. And parents in countries like Pakistan do not want to spend cash on girls' higher education they rather spend on their dowry as in Pakistan marriage is considered as an ultimate goal for girls' life.

Awan (2015) determined the factors affecting women empowerment for district of Punjab, the determinants included social, socio-economic as well as socio-demographic factors. Social factor includes fear of violence from husband/ father, Socio-economic factors include access to media, having bank account, employment status whereas, socio-demographic factor includes family system. All the variables were found to have positive influence on women empowerment, women empowerment in rural areas have some separate needs like household education, awareness in community regarding opportunities, important impression of media and awareness of Islamic educations about women rights. Urban women have access to all facilities of life whereas, rural women are deprived of all opportunities and according to findings in rural regions merely married women are endowed.

The previous paragraphs have shown literature related to determinants of women empowerment while this paragraph will explore literature related to women empowerment as a determinant. Many researchers have suggested a positive association among women empowerment and poverty alleviation, similarly, a study by Abdussalam, et.al., (2013) have found positive relationship between the two variables for Kwara State of Nigeria and similar results were found in case of Indonesia by (Tambunan \& Indonesia, 2005). According to Taramol, (2014) for enriching poor women from poverty, openings for them for economic involvement become compulsory. Economic contribution of women leads to their well position in the family and the study has proved without any uncertainty that women empowerment is the finest approach for poverty abolition.

In sum, women empowerment has different determinants in different regions and countries however, one of the variables like education have a persistent positive relationship in almost all researches jotted down in the literature review. Although, there is no single variable that affects women empowerment but there are multiple determinants determining women empowerment.

\section{Theoretical Background}

Amartya Sen's capabilities approach rotates round people as human-being; this realizes progress as growth of people's abilities and objectives to improve people's well-being by mounting their abilities which is linked to autonomy of choices. According to (Hill, 2003) Amartya Sen (1976, 1987, 1992, 1999b) has remained the chief philosopher of the capability approach to human well-being, an unconventional theory to old-fashioned welfare theory. As per the capability approach, an entity's accomplished well-being is appraised by seeing the level of her valued functioning's, or the "beings" and 
"doings" that she can accomplish. For example, let's say, this includes the liberty of choosing to have a child and other related decisions (David Crocker 1995: 154). Sens Capability approach uses fundamental human freedoms as the suitable evaluative measure of human well-being. Many researchers like (Bhattacharya and Banerjee,2012; Ballon, 2017) have used Sens Capability approach to study women empowerment focusing on different aspects of empowerment.

The term women empowerment is studied through different viewpoints, according to Abdussalam, et.al., (2010) women empowerment is defined through four dimensions, economic dimension which explains women's control over purchase and expense of households, decision making explains women's contribution in domestic decision-making, mobility tells women's liberty to visit diverse spaces and last dimension is communication. Furthermore, the determinants of women empowerment were explored; level of education, political involvement, and working for salaried job along with this age and husband's cooperation remained strong determining factor of women enablement.

However, theorizing female empowerment has remained a thought-provoking mission for conventional mechanisms of gender improvement. Empowerment has been theorized from diversity of social science disciplines. Findings from economics, anthropology and sociology describe empowerment as choice and control (Malhotra et al, 2002).

Ballon (2012) argued that empowerment is a multifarious concept. It is a vibrant procedure entrenched in the notion of human organization and choice. Its conceptualization and measurement, requires a general framework for capturing the interrelations among its constitutive elements: resources, values/preferences, decision-outcomes. Access to different capitals may surge the array of possible choices for women, nonetheless they are doubtful to lead to greater decision-outcomes consistently. Alternatively, they will differ according to the standards and predilections and the institutional norms of women. As well, an improvement in woman's decision-making capability differs within the kind of choice considered.

However, this study grounded on the previous theories filter all the variables related to women decision making regarding Health, Knowledge/Education and Autonomy in the literature to construct Women Empowerment Index. The indicators/dimensions used for construction of the empowerment indexes compromises multidimensional components which includes decision making power of women in are (i) Own marriage decision, (ii) Child marriage decision, (iii) Number of child decision, (iv) Child Control decision, (v) Own education decision, (vi) Household purchase decision, (vii) own medical treatment decision and (viii)visit decision and another women empowerment index based on women's participation at household and community level majorly focusing (i) Women's access to income (Control \& Expenditure), (ii) Household decision making regarding expenditures, (iii) Role in decision making regarding agricultural production and livestock (as we consider agriculture and livestock as outdoor activities so, we have included it in participation), (iv)Involvement of female in business, (v) role of female in Women Organizations (WO) and Local Support Organizations (LSO), (vi) Female having separate saving account any community organization and (vii) Women's leadership position in the community. The below diagram shows the conceptual framework of what we have done in on this study from elements to components to the determinants of women empowerment. 


\section{Path Analysis Diagram}

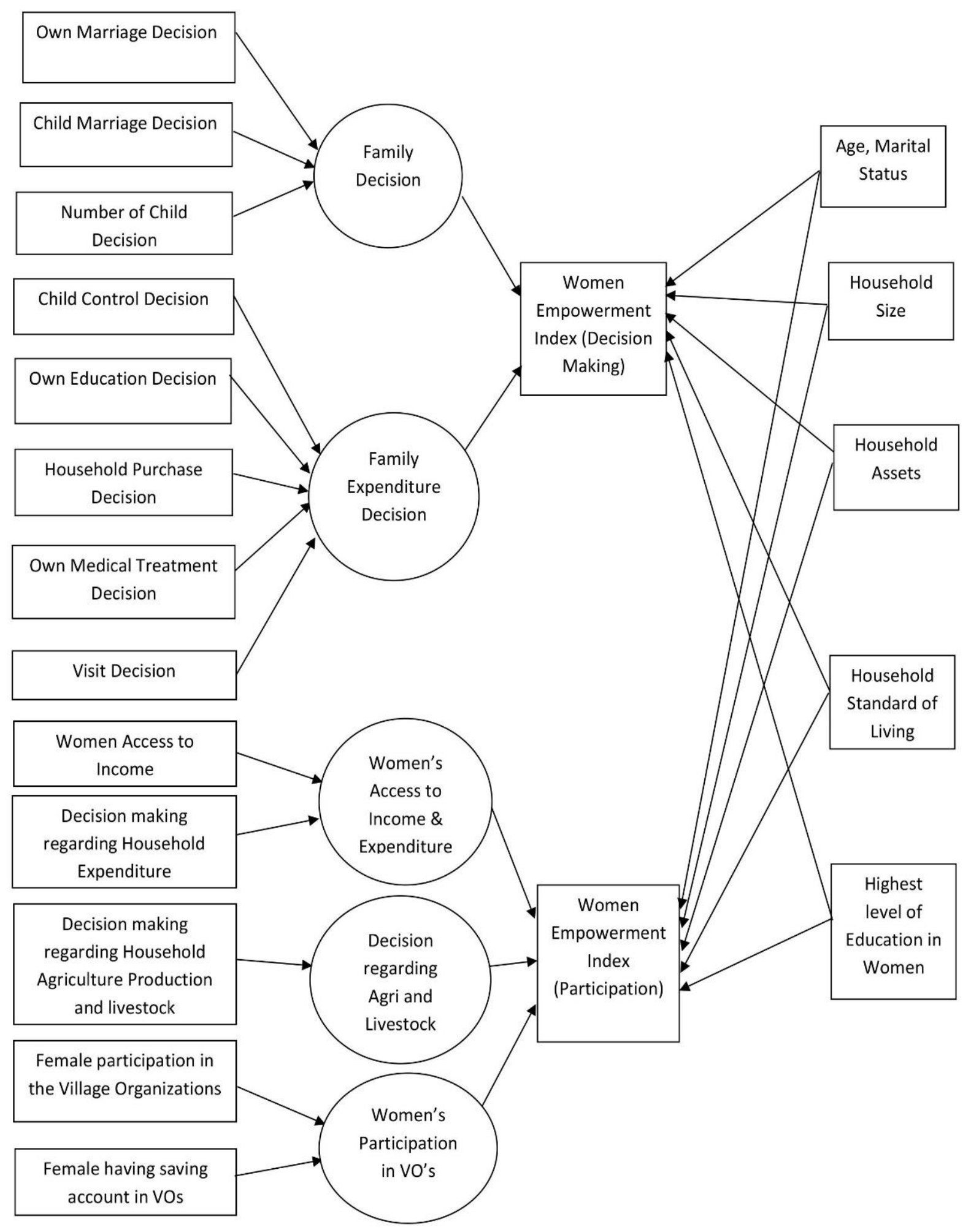




\section{Data and Methodology}

In order to analyse women empowerment in Gilgit, two stage cluster random sampling is used, from Gilgit two major districts Gilgit and Ghizer are opted further from these districts, villages are identified, and further $3 \%$ households of the total households are identified and used for analysis. The sample is extracted based on the population provided by Benazir Income Support Program (BISP) 2016-17. The total number of households selected on the $3 \%$ criteria were 860, out of 14,203 households in Gilgit 476 households were selected and from Ghizer region out of 8,317 households 384 households were selected for data collection. However, some of the questionnaires were discarded due to improper and incomplete information and the remaining 836 households out of 860 were for analysis purpose.

\subsection{Model to examine causes of Women Empowerment}

Two indexes are constructed to measure women empowerment, first one is based on involvement of women in decision making and second on women participation. As women empowerment is defined as a composite of certain group of variables, grounded on variables and based on the data this study investigates the following set of variables comprising some socio-economic and socio-demographic variables:

- Age, Marital Status, Ethnicity, Religious Affiliation and Household Size (SDs)

- Economic Condition of Household (Including Asset Index, Standard of Living Index) (SEs).

- Household's level of Education (Three measures of education are taken women education in the household, education of household head and average household education)

To evaluate the analytical strength of socio-economic and socio-demographic variables in empowerment of women, Path Analysis is carried out. Structural Equation Model tests assumed forms of directional and no directional associations between measured and latent variables (MacCallum \& Austin, 2000). A study of empowerment conducted by Ballon (2012) used structural equation model to examine different components and causes of women empowerment with emphasis on strategic choices and economic choices. This paper is also emphasizing on the self-strategic choices, choices regarding family size and family related decisions and participating domestic and outdoor works.

\section{Results}

Two major indices are constructed to determine women empowerment in Gilgit and Ghizer Region. First index is based on women's involvement in decision-making in social matters and expenses of the household. Second index of women empowerment is based on women's participation in social/community organizations and in household expenditures.

\subsection{Women Empowerment Index based on Decision making}

This women empowerment index is constructed based on the elements of decision making. It includes own \& child's marriage decision, number of child decision, child control decision, own education decision, household purchase decision, own medical treatment decision and visit decision listed in the table with factor loads. Principal component analysis (PCA) is applied to all decision related variables which gives weight to the indicators, based on the exploratory factor analysis factor loads allocated are multiplied with responses to form different components and these components are further multiplied with the variance of extraction sums of square loads and are linearly added to form women empowerment index as shown by (Suhr, 2015; Abeyasekera, 2005; Pomeroy et al.,1997). PCA is a multi-variable statistical procedure used to explain the disparity of a set of multivariate data in terms of a set of uncorrelated linear mixtures of variables (Khudri and Chowdhury, 2013). Researchers have used this technique to study women empowerment (Dey and Md, 2015; Jamal, 2017; Haq, Jali \& Islam, 2016). 


\section{Reliability Test}

Table 1 shows the reliability of the instruments for decision making is computed using Cronbach's alpha which is 0.84 greater than 0.6 the standard value alpha and it shows higher internal consistency. To check the sampling adequacy KMO and Bartlett's test is checked in factor analysis which is 0.83 shown in the below table. When the value is between 0.8 to 1 this means that the sampling is adequate.

Table 1: KMO and Bartlett's Test

\begin{tabular}{|l|l|l|}
\hline \begin{tabular}{l} 
Kaiser-Meyer-Olkin $\begin{array}{l}\text { Measure of Sampling } \\
\text { Adequacy. }\end{array}$ \\
\hline $\begin{array}{l}\text { Bartlett's Test of } \\
\text { Sphericity }\end{array}$
\end{tabular} & Approx. Chi-Square & 2334.58 \\
\cline { 2 - 4 } & Df & 28 \\
\cline { 2 - 3 } & Sig. & 0.000 \\
\hline Based on correlations \\
\hline
\end{tabular}

The factor loads given in Table 2 are extracted through factor analysis in Principal Component Analysis for components both components. All the indicators having weights more than 0.5 are kept and other variables are excluded.

Table 2: Factor Loads for Decision Making Index

\begin{tabular}{|l|l|l|}
\hline Variables/Components & Family Decision & Family Expenditure Decision \\
\hline Own Marriage Decision & & .778 \\
\hline Child Marriage Decision & & .799 \\
\hline Child Decision (Number of Child) & & .850 \\
\hline Child Control Decision & .805 & \\
\hline Own Education Decision & .528 & \\
\hline Household Purchase Decision & .813 & \\
\hline Own Medical Treatment Decision & .791 & \\
\hline Visit Decision & .804 & \\
\hline
\end{tabular}

Source: Author's estimation Extraction Method: Principal Component Analysis

The below table 3 shows the rescaled values of variance of both the components used in decision making index based on the principal component analysis. According to the extraction method PCA, when analyzing a covariance matrix, the initial eigenvalues are the same across the raw and rescaled solution.

Table 3: Extraction sums of square loads

\begin{tabular}{|l|l|l|l|}
\hline Components & Total & \% of Variance & Cumulative \% \\
\hline Family Decision & 3.720 & 46.496 & 46.496 \\
\hline Family Expenditure Decision & 1.445 & 18.068 & 64.565 \\
\hline
\end{tabular}

Extraction Method: Principal Component Analysis

\subsection{Women Empowerment Index based on Women Participation and Empowerment}

This index of women empowerment based on participation in household activities regarding expenditures and participation outside home is also calculated using PCA like empowerment on decision making.

\section{Reliability Test}

The scaling of instruments for this index of empowerment had two option Yes and No so, the reliability of instruments is examined separately. The reliability of the instruments for women empowerment based on 
women's participation in household and at community level is also computed using Cronbach's alpha which is 0.66 greater than 0.65 the standard value alpha and it shows the internal consistency. To check the sampling adequacy KMO and Bartlett's test is checked in factor analysis which is 0.63 shown in the below table 4 . When the value is between 0.8 to 1 this means that the sampling is very adequate however for this index the KMO and Bartlett's coefficient is average which is acceptable.

Table 4: KMO and Bartlett's Test

\begin{tabular}{|l|l|l|}
\hline Kaiser-Meyer-Olkin Measure of Sampling Adequacy. & .634 \\
\hline \multirow{3}{*}{ Bartlett's Test of Sphericity } & Approx. Chi-Square & 2077.87 \\
\cline { 2 - 3 } & df & 66 \\
\cline { 2 - 3 } & Sig. & 0.000 \\
\hline
\end{tabular}

The factor loads given for the index of participation through factor analysis using Principal Component Analysis are given in the table below 5. Likewise, here the indicators having weights of more than 0.5 are extracted to form the components and others are deleted.

Table 5: Factor Loads for Women Participation

\begin{tabular}{|l|c|c|c|}
\hline \multicolumn{1}{|c|}{ Index } & \multicolumn{2}{c|}{} \\
\hline Components & 1 & 2 & 3 \\
\hline Women in WO & .938 & & \\
\hline Women in house having saving account in WO/society & .867 & & \\
\hline Women Access to Income & & .874 & \\
\hline Role in decision making regarding HH agriculture production and livestock & & .714 & \\
\hline Role of women in decision making in Household Expenditures & & & .962 \\
\hline
\end{tabular}

Source: Author's Estimation using Extraction Method: Principal Component Analysis

The below table 6 shows the variances for all the components used to form women participation index.

Table 6: Extraction Sums of Squared Loadings for women participation

\begin{tabular}{|l|l|l|l|}
\hline Components & Total & $\begin{array}{l}\% \\
\text { Variance }\end{array}$ & $\begin{array}{l}\text { Cumulative } \\
\%\end{array}$ \\
\hline $\begin{array}{l}\text { Women as a member of WO or have saving account } \\
\text { in WO/Society }\end{array}$ & $\begin{array}{l}2.22 \\
0\end{array}$ & 24.668 & 24.668 \\
\hline $\begin{array}{l}\text { Women Access to Income \& Role in decision making } \\
\text { regarding } \\
\text { HH agriculture production and livestock }\end{array}$ & 9 & 15.383 \\
\hline Role of women in decision making in Household Expenditures & .658 & 7.313 & 40.101 \\
\hline
\end{tabular}

Source: Author's Estimation Extraction Method: Principal Component Analysis

\subsection{Comparison of women empowerment indexes across Districts, Sects and Languages}

The table 7 shows the comparison of women empowerment across two districts Gilgit and Ghizer. The range of scores for women participation and women decision making are different, women participation responses lie between 0 and 1 where, zero indicates 'No' and 1 indicates 'Yes'. Whereas the responses for women decision making index vary from 1 to 3, ' 3 ' showing that women in the household makes decision by their own, ' 2 ' indicates that women are consulted and ' 1 ' indicates they are not consulted. The values for women participation index are quite low for both regions Gilgit and Ghizer showing low participation of women however, Gilgit district is showing a relatively high participation level. The scores for women 
decision making index indicates a relatively high level of empowerment in Ghizer as compared to Gilgit. As both these districts are still somehow backward and are in their initial stages of development therefore, the scores for women participation and decision making indexes are low.

Table 7: Women Empowerment Index Comparison across districts

\begin{tabular}{|l|l|l|}
\hline District & Women Participation Index & Women Decision Making Index \\
\hline Ghizer & 0.30 & 3.52 \\
\hline Gilgit & 0.37 & 3.23 \\
\hline
\end{tabular}

Sources: Authors estimations based on the primary data

\subsubsection{Comparison of women empowerment across sects}

Table 8 shows scores for women empowerment decision making and participation. It means that religion in Gilgit and Ghizer has significant impact on the women empowerment in both contexts of participation and decision making. The scores 0.48 for Women Participation index shows that women of Shia community are more empowered than Ismaili and Sunni in the region with scores 0.37 and 0.16 respectively whereas the score 3.68 for women decision index show that women of Ismaili community are more empowered than other communities in terms of decision as compared to Sunni and Shia with respective scores of 2.75 and 3.54. According to Brajesh and Shehkar, (2015) women empowerment heavily depends upon social status of women, religious and cultural experiences show noteworthy parts in affecting women's empowerment in all countries. Gilgit Baltistan displays a strong variation on language, sect and ethnic lines (Zain, 2010). The district Ghizer is dominated by Ismailis (87 percent) who belong to Brusho ethnic group and speak Shina, Khowar and Brushashki (Ameer, 2002). The districts Gilgit and Hunza have a mixed population with Shias (54 percent) having Brusho, Shin and Yashkun identities and they are Shina, Brushashki and Wakhi language speakers.

Table 8: Comparison of Women Empowerment across Sects

\begin{tabular}{|l|l|l|}
\hline Sect & Women Participation Index & Women Decision Making Index \\
\hline Ismaili & 0.37 & 3.68 \\
\hline Sunni & 0.16 & 2.75 \\
\hline Shia & 0.48 & 3.54 \\
\hline
\end{tabular}

Sources: Authors estimations based on the primary data

\subsubsection{Comparison of women empowerment indexes across Languages}

Among the languages, women participation index depicts high score in Burushaski speakers as compared to other languages and for women decision making Khuwar speakers have high score among other languages as shown in table 9.

Table 9 Women Empowerment across Languages

\begin{tabular}{|l|l|l|}
\hline Language & Women Participation Index & Women Decision Making Index \\
\hline Shina & 0.31 & 3.10 \\
\hline Burushaski & 0.45 & 3.73 \\
\hline Khuwar & 0.24 & 3.87 \\
\hline Others & 0.25 & 3.18 \\
\hline
\end{tabular}

Sources: Authors estimations based on the primary data 


\section{Regression Results and Discussion}

The below table shows two models and relationship among the dependent and independent variables using Structural Equation model. According to the results of structural equation models of women participation and women decision it is observed that Age of head of the household no significant relationship with both models. Some studies have shown significant relationship between these variables in the past in different however, in this context both these variables have insignificant relationship.

Table 10: Regression Results

\begin{tabular}{|l|l|l|}
\hline Variables & $\begin{array}{l}\text { Women Empowerment Decision Making } \\
\text { Index (WEDI) }\end{array}$ & $\begin{array}{l}\text { Women } \\
\text { Participation Index (WEPI) }\end{array}$ \\
\hline Age & -.0039 & 0.0004 \\
$(.00269)$ & $(0.0009)$ \\
\hline Marital Status (MS) & -.206 & -0.005 \\
& $(.1364)$ & $(0.046)$ \\
\hline Household Size & .0215 & 0.010 \\
$(0.0134)$ & $(0.004)^{* * *}$ \\
\hline $\begin{array}{l}\text { Women's Highest level } \\
\text { of Education }\end{array}$ & $\begin{array}{c}\mid c .042 \\
(0.0085)^{* * * *}\end{array}$ & $\begin{array}{c}0.013 \\
(0.029)^{* * *}\end{array}$ \\
\hline $\begin{array}{l}\text { Standard of Living } \\
\text { Index }\end{array}$ & -.213 & -0.044 \\
& $(0.840)^{* * *}$ & -.0091 \\
Asset Index & -.358 & $(0.0942)^{* *}$ \\
\hline
\end{tabular}

Sources: Authors estimations based on the primary data $(* * *$ shows significance level at $1 \%$, ** significance level at $5 \%$ and $*$ shows significance at $10 \%$.)

Education is one major determinant of women as studied by many researcher's Shoaib, Saeed and Cheema, 2012 investing in women's empowerment is the very important to uplift the economic, political and social conditions in Pakistan and to make women empowerment it's imperative to spent on their education. Education makes women attentive about their rights, duties, choices and independence. The results for Gilgit and Ghizer districts are in accordance with the study conducted in rural Punjab, showing positive connection among level of education and women empowerment for both decision making and participation. The maximum the level of education of women in the household the more empowered are those women in terms of decision making and participation. As the level of education increases by 1 unit, women decision making increases by 0.04 at 1 percent and women participation alters by 0.013 at 1 percent significance. Likewise, a study by (Ashraf \& Farah, 2007) examined that empowerment and education are positively related, education adds extra aspects to women's conventionally recognized roles and makes them more empowered. Evidence from southern Punjab by Haq, Jali and Islam (2017) also supports the positive relationship of women empowerment and education level of women. Education helps in enhancing human resources, standard of life and boosts economic growth. Similarly, another studied reveals that the main reason why women are exploited and not given their basic rights is due to lack of knowledge about women's right (Sharma, 2003). To make women learn about their social and political rights it's really important to give them education (Khan et al., 2015).

A study reveals that to boost the financial position of women, it is imperative to make them empowered and by making them empowered, and this can enhance their economic condition in the household or at country level (Niaz, Askar \& Javeed, 2010). This means that the better their economic status the more empowered are the women. This study has used different measures to measure the economic status of households including, standard of living index, income, and asset index. Out of all these three measures, the standard of living index used to measure economic well-being of households is showing significant association with women decision making index which means that as the economic status of household 
increases women are more empowered in terms of decision making. As Standard of living increases by one unit, women empowerment changes by -.214 showing significance at 1 percent. Asset index is showing an insignificant relationship with decision making index but it is showing a significant and negative impact with Women Participation Index with a magnitude of -.19 at 5 percent. This means that having more household assets decreases women participation in outdoor activities and organizations and they are involved more in household activities whereas it does not influence the women's decision making at household level.

Family structure is another determinant which can influence women's independence Debnath, 2015 showed the effect of family structure on women autonomy and have explored that women living in conjugal households have more decision-making power than people living in joint family. This study has used average household size to measure family structure. The results show an insignificant relationship with women decision index whereas with women participation average household size is showing positive and significant relationship. As average household size increases by one unit, women participation inclines by 0.01 units with a significance level at 1 percent. This means that when there are more people in the household, women get the chance to participate in household as well as at community level. Females in the households with more individuals are more empowered in terms of participation.

To examine the overall significance of the models goodness of fit is used. Given the Chi-square sensitivity for sample size, authors (see Hox \& Bechger, 1998; Kline, 2015) assert that one can use Root Mean Square Error of Approximation (RMSEA), Comparative Fit Index (CFI) and Standardized Root Mean Square Residual (SRMR) to assess model fit. The dependency of such measures on sample size is smaller than that of standard chi-square test (Hox \& Bechger, 1998). RMSEA assesses how well a given model approximates the true model. RMSEA should be less than 0.05 and in our model, it is 0.000 , which is significantly lower than the standard threshold. Other fit indices - CFI and SRMR- are also under the threshold. Hence, based on the results of these indices we assume that our model is fit for estimation and to test the hypothesis.

\section{Conclusion \& Policy Recommendations}

This study based on the cross-sectional household data from Ghizer and Gilgit and extracted using Principal Component Analysis (PCA) shows that Ghizer is more empowered than Gilgit in terms of decision making and Gilgit is more empowered than Ghizer in terms of women participation. Women residing in the Gilgit district have more opportunities as compared to people living in the far flung areas of Ghizer district. Among the sect's women belonging to Shia community are more empowered in terms of women participation whereas for women decision making women belonging to Ismaili community are more empowered.

The results grounded on structural equation modelling used to examine the determinants of women decision making and women participation reveal that education level is mandatory to boost women's decision making at household level and to make them capable in terms of participation. Moreover, the study discloses that having better household standard also improves empowered in decision making. And having more household assets discourage women participation meaning that when women have more household assets they are more inclined to household activities. Family size has no significant effect on women decision making but has a significant and positive effect on women participation. The more the number of people in the household the greater will be women participation. So family structure can sometimes be beneficial for women as they get more chance to participate in household activities as well as outside the home.

4 The standard of living index is composed in such a way that as you move from higher value to 1 , the standard of living improves. The closer the households average index value is to 1 the higher is the standard of living. 
Therefore, it can be concluded that level of education of women is very important to make them capable in every dimension of women empowerment either decision making or participation. There are some areas in Gilgit and Ghizer where very less of women are educated and girls are still out of school or have left schools earlier. Government should establish new schools and college in the regions where there is need and the already established schools, colleges and universities should be enhanced in terms of quality. This will not only make women learn about their basic rights and freedom perhaps this will make them economically empowered. Participation of women in labor market will enhance household standards as well as will benefit the economy of the country.

\section{References}

Abeyasekera, S. (2005). Chapter XVIII Multivariate methods for index construction. Reading (UK): University of Reading. hlm, 377-378

Ameer, Saadullah (2002). Shumali Illaqa Jat: Eik Nazar. Nadir Printers, Gilgit.

Ashraf, D., \& Farah, I. (2007). Education and women's empowerment: Re-examining the relationship. Education, gender and empowerment: Perspectives from South Asia, 15.

Awan, S. Z. (2016). Relevance of education for women's empowerment in Punjab, Pakistan. Journal of International Women's Studies, 18(1), 208.

Azra Batool, S., Ahmed, H. K., \& Qureshi, S. N. (2018). Impact of demographic variables on women's economic empowerment: An ordered probit model. Journal of women \& aging, 30(1), 6-26.

Ballon, P. (2011). A Structural Model of Female Empowerment '. P. Ballon, Modelbased Multidimensional Poverty Indices: Theoretical Construction and Statistical Properties. Doctoral Dissertation, Thesis, (759).

Bhattacharya, J., \& Banerjee, S. (2012). Women empowerment as multidimensional capability enhancement: An application of structural equation modeling. Poverty \& Public Policy, 4(3), 7998.

Brajesh \& Shekhar, C. (2015). Level of Women Empowerment and its determinates in selected South Asian Countries. Journal of Humanities and Social Science, 20(4), PP 94-105.

Chaudhry, I. S., Nosheen, F., \& Lodhi, M. I. (2012). Women empowerment in Pakistan with special reference to Islamic viewpoint: An empirical study. Pakistan Journal of Social Sciences, 32(1), 171-183.

Debnath, S. (2015). The impact of household structure on female autonomy in developing countries. The Journal of Development Studies, 51(5), 485-502.

developments. Cambridge, UK: Cambridge University Press.

Dey, R., \& Md, M. K. (2015). Assessment of key dimensions and determinants of women's empowerment in Bangladesh. Russian Journal of Agricultural and Socio-Economic Sciences, $37(1)$.

Floro, M. S., Tornqvist, A., \& Tas, E. O. (2009). The Impact of the Economic Crisis on Women's Economic Empowerment. Swedish International Development Agency Çalışma Metni Serisi: http://www1. american. edu/academic. depts/cas/econ/workingpapers/2009-26. pdf (Erişim tarihi: Ekim 2010).

Greene, W. H., \& Hensher, D. A. (2010). Modeling ordered choices: A primer and recent

Hilali, Wahid Beig (1995). Hikayat-e-Baltistan. Baltistan Book Depot, Skardu.

Abdussalam, O. I., Johari, F., \& Alias, M. H. (2013). The determinants of women empowerment and its impact on poverty alleviation: A case of Kwara State, Nigeria (A Pilot Study). Asian Journal of Social Sciences \& Humanities, 2(4), 342-347.

Hill, M. (2003). Development as empowerment. Feminist economics, 9(2-3), 117-135.

Hox, J. J., \& Bechger, T. M. (1998). An Introduction to Structural Equation Modeling. Family Size Review, 11, 354-373.

Jamal, H. (2017). Explaining Spousal Physical Violence through Dimensions of Women Empowerment: Evidence from Pakistan. Retrived from https://mpra.ub.uni-muenchen.de/83414/.

Kabeer, N. (2003). Gender Mainstreaming in Poverty Eradication and the Millennium Development Goals: A handbook for policy-makers and other stakeholders. Commonwealth Secretariat. 
Khan, R. E. A., Rehman, H., \& Haq, M. A. (2015). Determinants of rural household poverty: the role of household socioeconomic empowerment. American-Eurasian J. Agric. \& Environ. Sci, 15(1), 9398.

Khan, S. U., \& Awan, R. (2011). Contextual assessment of women empowerment and its determinants: Evidence from Pakistan.

Khudri, M.M. and Chowdhury, F. 2013. Evaluation of Socio-economic status of households and identifying key determinants of poverty in Bangladesh. European Journal of Social Sciences 37(3): 377-387.

Kline, Rex B (2015). Principles and Practice of Structural Equation Modeling. Guilford Publications.

Malhotra, A., S. Schuler and C.Boender (1998-2004). Measuring women's empowerment as a variable in international development. Paper commissioned by the Gender and Development Group of the World Bank.

Mandal, K. C. (2013, May). Concept and Types of Women Empowerment. In International Forum of Teaching \& Studies (Vol. 9, No. 2).

Mehra, R. (1997). Women, empowerment, and economic development. The Annals of the American Academy of Political and Social Science, 554(1), 136-149.

Mohsin Khan \& Qurat-ul-Ain Ali, 2016. Socio-Economic Empowerment of Women in Pakistan; Evidences from Gilgit-Baltistan. International Journal of Asian Social Science, Asian Economic and Social Society, vol. 6(8), 462-471.

mpra.ub.uni-muenchen.de/24740/.

Murtaza, K. F. (2012). Women empowerment through higher education in Gilgit-Baltistan. International Journal of Academic Research in Business and Social Sciences, 2(9), 343.

Nayak, P., \& Mahanta, B. (2009). Women empowerment in India. Retrieved from http://

Niaz, M., Ali, A., \& Rukhsana, J. (2010). Socio-economic impacts of women's empowerment in Peshawar, Pakistan. Sarhad Journal of Agriculture, 26(3), 461-465.

Noreen, G., \& Khalid, H. (2012). Gender empowerment through women's higher education: Opportunities and possibilities. Journal of Research and Reflections in Education, 6(1), 50-60.

Noureen, G. (2015). Education as a Prerequisite to Women's Empowerment in Pakistan. Women's Studies, 44(1), 1-22.

Parveen, S., \& Leonhäuser, I. U. (2005). Empowerment of rural women in Bangladesh: A household level analysis (Vol. 72). Berlin, Germany: Margraf.

Pomeroy, J. W., Fang, X., Shook, K., \& Whitfield, P. H. (2013). Predicting in ungauged basins using physical principles obtained using the deductive, inductive and abductive reasoning approach. Putting prediction in ungauged basins into practice, 43-63

Rahman, M., Karmaker, U. K., \& Mia, A. R. (2009). Determinants of women empowerment at domestic and non-domestic issues: Evidence from Chapai Nawabganj district in Bangladesh. Dhaulagiri Journal of Sociology and Anthropology, 3, 143-162.

Shoaib, M., Saeed, Y., \& Cheema, S. N. (2012). Education and Women's Empowerment at Household Level: A Case Study of Women in Rural Chiniot, Pakistan. Academic Research International, 2(1), 519.

So, Y., \& Kuhfeld, W. F. (1995). Multinomial logit models. In SUGI 20 conference proceedings (pp. 1227-1234).

Soharwardi, M. A., Khan, A. S., \& Khalid, M. Socio-economic Determinants of Women Empowerment: A Case Study of Cholistan Desert, Pakistan.

Suhr, D. D. (2005). Principal component analysis vs. exploratory factor analysis (paper 203-30). In Proceedings of the thirtieth annual SAS® users group international conference (Vol. 203, p. 30).

Sultana, A. M. (2011). Factors effect on women autonomy and decision-making power within the household in rural communities. Journal of Applied Sciences Research, 7(1), 18-22.

Tambunan, T., \& Indonesia, L. K. (2005). Linkages between Macroeconomic Reform Policies, Shocks, and Poverty Reduction: The Indonesian Case. In Macroeconomic Policy Challenges in Low Income Countries Conference, International Monetary Fund, February (pp. 15-16). 
Tareque, M. I., Haque, M. M., Mostofa, M. G., \& Islam, T. M. (2007). Age, age at marriage, age difference between spouses and women empowerment: Bangladesh context. Middle East Journal of Age \& Ageing, 4(6), 8-14.

Wiklander, J. (2010). Determinants of women's empowerment in rural India: An intra-household study (Unpublished master's thesis). Lund University, Lund, Sweden. Retrieved from http://lup.lub.lu.se/luur/download?func=downloadFile\&recordOId=1666646\&fileOId= 1666649

Zain, O. F. (2010). A Socio-Political Study of Gilgit Baltistan Province. Pakistan Journal of Social Sciences (PJSS), 30(1). 


\section{Annexure}

\begin{tabular}{|c|c|}
\hline Variables & Description \\
\hline $\begin{array}{l}\text { Women Empowerment Index } \\
\text { (Decision Making Index) }\end{array}$ & This is index is an aggregate of married women's decision making \\
\hline $\begin{array}{l}\text { Women Empowerment Index } \\
\text { (WEPI) }\end{array}$ & $\begin{array}{l}\text { Based on women participation and empowerment in } \mathrm{HH} \text { as well as } \\
\text { society }\end{array}$ \\
\hline Wages & Wages is defined as cash by the household \\
\hline Ethnicity & $\begin{array}{l}\text { Ethnicity refers to proportion of sample belonging to the defined } \\
\text { languages }\end{array}$ \\
\hline Religious Affiliation & $\begin{array}{l}\text { Religious Affiliation shows the proportion of sample belonging to } \\
\text { defined religious groups }\end{array}$ \\
\hline Age & Age of Head \\
\hline Years of Education & Highest level of education of women in household \\
\hline Income/Per Capita Income & $\begin{array}{l}\text { The proxy for Income is Per Capita Income which is defined as the } \\
\text { total income earned divided by household size }\end{array}$ \\
\hline Household Size & Average number of people living a house \\
\hline Health Facility & \\
\hline Asset Index & A composite index of all durable assets owned by households \\
\hline Standard of Living Index & A composite Index of all the facilities available for households \\
\hline
\end{tabular}

